ISSN: $1679-3013$

\title{
SEASONAL VARIABILITY OF THE AMAZON RIVER PLUME DURING REVIZEE PROGRAM
}

Recebido em: / /

Aceito em: / /

\author{
Alex Costa da SILVA ${ }^{1}$ \\ Moacyr ARAUJO ${ }^{1}$ \\ Bernard BOURLÈS ${ }^{2}$
}

\begin{abstract}
RESUMO
A costa oceânica norte do Brasil é uma região atipicamente energética e sujeita a significativas forçantes geofísicas que variam sazonalmente, tais como a descarga continental do Rio Amazonas, o transporte de fronteira oeste da Corrente de fronteira Norte do Brasil e a ação dos ventos alísios. As informações hidrográficas utilizadas neste artigo são provenientes de quarto cruzeiros oceanográficos realizados na borda oeste do Atlântico equatorial, como parte das atividades do Programa Brasileiro de Avaliação do Potencial Sustentável de Recursos Vivos da Zona Econômica Exclusiva. Estes períodos cobriram diferentes épocas do ano, caracterizadas pela variabilidade das forçantes continentais e oceânicas, ou seja: descarga máxima dos rios nos períodos correspondentes ao Inverno/Primavera boreal (Março-Maio 1995/Maio-Junho 1999); fase de decaimento da vazão fluvial no Verão (Julho-Agosto 2001), e fluxo continental mínimo durante o Outono boreal (Outubro-Novembro 1997). Estes dados indicaram que as águas amazônicas (Salinidade < 35.0) são formadas próximo à desembocadura do Rio Amazonas, quando as águas doces se misturam com as águas costeiras. A pluma do rio de estende até $300 \mathrm{~km}$ mar adentro durante o período de máxima descarga e até $50 \mathrm{~km}$ na época de aporte fluvial mínimo. Em ambas as situações, a halocilna se localizou a cerca de $20 \mathrm{~m}$ de profundidade. Os resultados indicaram também que durante a fase de transição das descargas (JulhoAgosto 2001) as águas doces continentais são transportadas para sudeste, ao longo da costa, fenômeno que se mostra menos evidente no Verão boreal e totalmente ausente no Outono. Os resultados numéricos confirmam que as Lentes de Água Amazônica foram efetivamente transportadas para Leste em Julho-Agosto 2001, como resultado do transporte das águas pela retroflexão da Corrente Norte do Brasil que ocorre próximo à latitude $8^{\circ} \mathrm{N}$.
\end{abstract}

Palavras chave: Região Costeira Norte do Brasil, Lentes de Água Amazônica, Programa REVIZEE, Simulação numérica.

\section{ABSTRACT}

The north Brazilian shore is an unusually energetic coastal region that is subjected to strong seasonally-driven variables, such as the Amazon River discharge, North Brazil Current transport, and trade winds. The hydrographic measurements used in this paper come from four cruises of the Brazilian Exclusive Economic Zone Program in the western equatorial Atlantic covered different seasonal periods and situations of river discharge: maximum outflow in boreal late Winter/Spring (March-May 1995/May-June 1999), falling river discharge period in Summer (July-August 2001), and minimum out flow in Fall (October-December 1997). These unpublished field data indicated that the Amazonian Water Lenses (Salinity values < 35.0) are formed near the Amazon River mouth as freshwater mixed with shelf water. The river plume extended $300 \mathrm{~km}$ offshore during maximum discharge, and $50 \mathrm{~km}$ during minimum discharge. In both situations the halocline is placed at about $20 \mathrm{~m}$ depth. Results have shown that during boreal late Winter and

Contatos: ${ }^{1}$ Laboratório de Oceanografia Física Estuarina e Costeira, Departamento de Oceanografia da Universidade Federal de Pernambuco - LOFEC/DOCEAN/UFPE. Av. Arquitetura s/n, 50740-550, Campus Universitário, Recife, PE, Brazil

e-mail: alex.csilva@ufpe.br

${ }^{2}$ Institut de Recherche pour le Développement, 08 B.P. 841 - Cotonou, Bénin. 
SILVA, A. C. da; ARAUJO, M.; BOURLÈS, B. Seasonal variability of the Amazon river plume during Revizee program.

Spring the Amazonian Water Lenses moved southwestward along the coast in the north of Brazil, which is less evidently verified in boreal Summer and really not observed during Fall. Model simulations have confirmed that the freshwater lenses are transported eastward during August 2001, as resulting of the retroflection of the North Brazilian Current around $8^{\circ} \mathrm{N}$.

Key words: North Brazilian Shore, Amazonian Water Lenses, Program REVIZEE, Numerical simulation.

\section{INTRODUCTION}

The Amazon River basin extends from the Andes across the low Amazon rainforest, with an catchments area of approximately $7 \times 106 \mathrm{~km} 2$. The mean Amazon River discharge is about $0.15 \mathrm{~Sv}$ ( $1 \mathrm{~Sv}=106 \mathrm{~m} 3 . \mathrm{s}-1)$, being responsible for about half of all freshwater input into the tropical Atlantic (BAUMGARTNER AND REICHEL, 1975; YOO AND CARTON, 1990). This rate varies $50 \%$ between a maximum in May-June to a minimum in November-December (RICHEY et al., 1989; CARTON, 1991). This fresh water contains an enormous amount of suspended matter which has an important influence over the coastal geomorphology of the northwestern coasts of South America (PROST, 1989) and over nutrient chemistry and biological productivity in the western tropical Atlantic (CALEF AND GRICE, 1967; GIBBS, 1970; CADEE, 1975; SANTOS, 2008) as far as the eastern Caribbean (RYTHER et al., 1967; FROELICH et al., 1978; KIDD and SANDER, 1979). The enormous Amazonian flow causes a large input of dissolved components and particles into the ocean, and freshwater fluxes have shown to be responsible for significant changes in surface thermodynamic properties of large extensions of the tropical Atlantic ocean (PAILLER et al., 1999). Most recently Ffield (2005) suggests that the Amazonian plumes are potentially important to tropical cyclone evolution, once the plume waters are correlated to the warmest temperatures observed in the region.

The Amazon Shelf region is dominated by the trade winds, with maximum stress corresponding to the northeast trade winds between the months of December and April, which are oriented roughly perpendicular to the coast (GEYER et al., 1996). The major ocean current reaching the Amazon shelf is the North Brazil Current (NBC), a strong western boundary current which originates in the South Equatorial Current (SEC) and flows across the Equator along the continental margin. According to Johns et al. (1998), the magnitude of NBC shows a significant seasonal variation at $40 \mathrm{~N}, 45^{\circ} \mathrm{W}$ ranging from a maximum transport of $36 \mathrm{~Sv}$ in July-August, to a minimum of $13 \mathrm{~Sv}$ in April-May, with an annual mean value of approximately $26 \mathrm{~Sv}$.

Publications based on satellite observations (SeaWIFS) data collected in Sept. 1997 Jun. 2002 demonstrate the Amazon freshwater during June-Sept at about $8^{\circ} \mathrm{N}$ and $47.5^{\circ} \mathrm{W}$ as it became entrained in the retroflection of the NBC, carried east by the North Equatorial Counter Current (NECC) (HU et al., 2004). This east flow reaches its maximum value during September 1999 and is weakest during March-April 1999 and April 2000 when the NECC reverses or is not present in the basin (GARZOLI et al., 2004).

Paradoxically, the displacement of the Amazonian Water Lenses (hereafter AWL) throughout the tropical Atlantic and their seasonal variability are still not sufficiently known. From historical hydrographic data, Dessier and Donguy (1994) and Lentz (1995a) show that there are two notable seasonal variations; the AWL extend offshore within the retroflection of the NBC during boreal Summer-Fall and alongshore toward the Caribbean during WinterSpring. Lentz (1995a, 1995b) also discusses about the mean size and structure of the AWL, and interprets their seasonal and spatial changes in the Amazon mouth according to the variability of the river discharge and local wind.

Field observations used herein were obtained as part of the proposed activities of the Program REVIZEE (Assessment of the Sustainable Potential of the Living Resources of the Exclusive Economic Zone). The REVIZEE is an interdisciplinary research program involving some of the major Brazilian Governmental Agencies and private fishery organizations. This Program is composed by different projects dealing with a variety of oceanographic 
disciplines including physics, chemistry, ecology, remote sensing, fish biology and population dynamics, and fishing technology.

In this study, we present a large amount of surface synoptic data colleted during four oceanographic cruises performed in 1995, 1997, 1999 and 2001 in the Brazil program "REVIZEE/SCORE-NO". These data are compared to high-resolution model results issued from the French CLIPPER Project. From the combination of hydrographic seadata and model outputs we investigate the Amazonian Water Lenses evolution and their spatial and time characteristics. The information is compared to climatology (LENTZ, 1995a; DESSIER and DONGUY, 1994) and observations carried out during the Multidisciplinary Amazon Shelf Sediment Study (AMASSEDS: LIMEBURNER et al., 1995; LENTZ and LIMEBURNER, 1995; LENTZ, 1995b; GEYER et al., 1996) off the Amazon mouth. We focus our analysis on the temporal and spatial evolution of the Amazonian continental waters to provide further insights about the inter-annual variability of AWL under the influence of the NBC its eddy retroflection.

\section{STUDY AREA}

The total study area comprehends a section of the North Brazil Shore, limited by the $2.5^{\circ} \mathrm{S}$ and $8^{\circ} \mathrm{N}$ in latitude and the longitude $40^{\circ} \mathrm{W}$ and $52^{\circ} \mathrm{W}$ (Fig. 1). Defined broadly, the Amazon system actually contains two river mouth areas, the Amazon proper to the north that contains the North Channel and the South Channel, and a secondary mouth delta defined by the river Pará to the south. The Marajó, the largest fluvial island in the world, separates these two river-mouth areas. Thus, the drainage of the Amazon into the Atlantic ocean includes the mouths of the Amazonas and Pará rivers, which consist in a complex delta having at least $300 \mathrm{~km}$ wide. The southeast of the southern Amazon mouth area, which extends from near Belém (PARÁ STATE) to Maranhão has relatively small coastal fluvial-drainage systems and development of numerous small-scale estuaries (ex. Gurupi and Parnaiba rivers). The Amazon continental shelf extends seawards in a gentle slope from the Pará River Mouth (Pará State, Brazil), about $5^{\circ} \mathrm{N}$, until Cabo Orange (Amapá State, Brazil); in front of the Amazon River Mouth, the continental shelf reaches up to $330 \mathrm{~km}$ in extension. 
SILVA, A. C. da; ARAUJO, M.; BOURLÈS, B. Seasonal variability of the Amazon river plume during Revizee program.

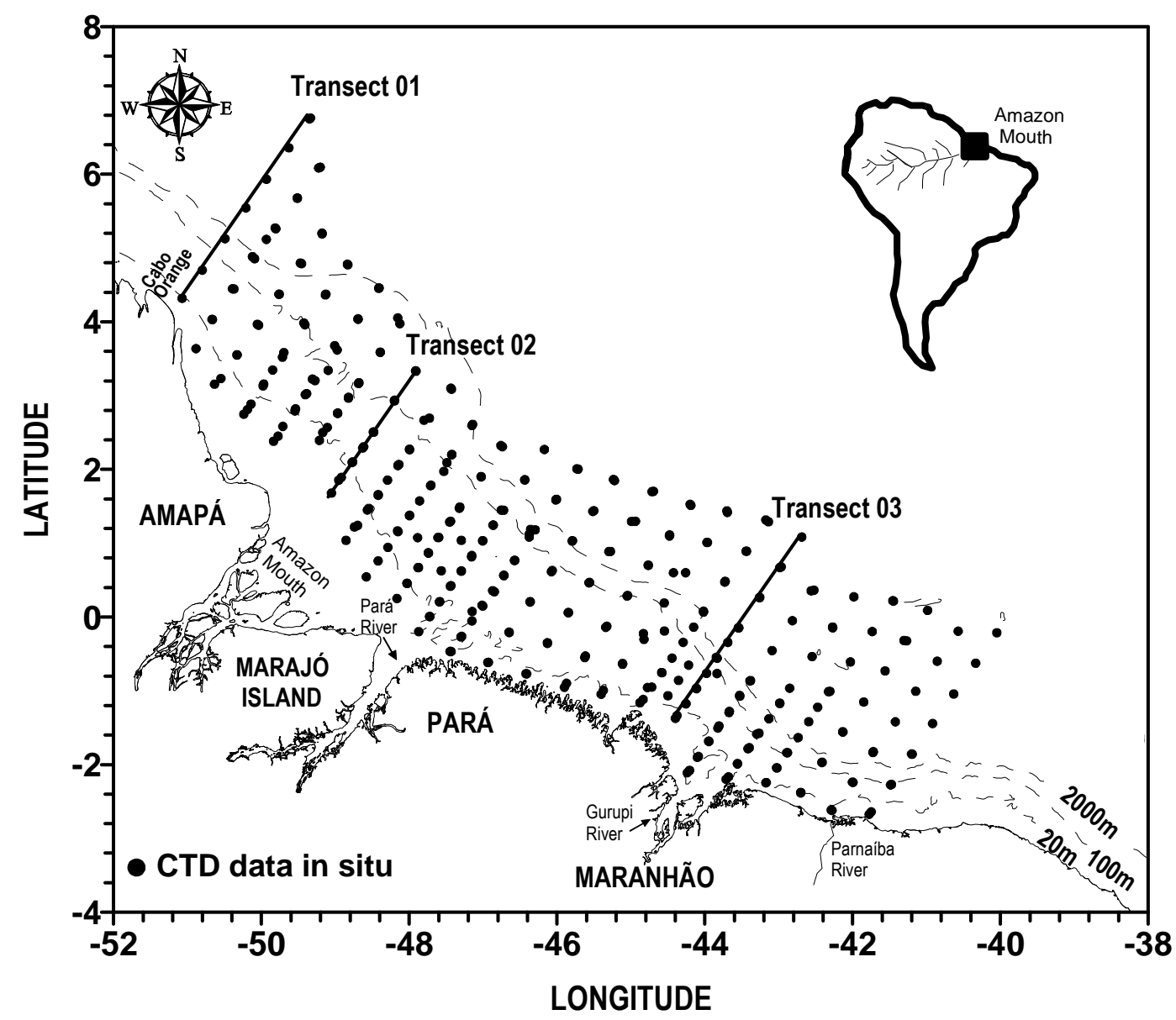

Figure 1 -Map of the Amazon shelf and adjacent oceanic area, showing the location of the CTD stations; location of the three examined Transects: $500 \mathrm{~km}$ north of the Amazon River (Transect 1); in front of the Amazon River mouth (Transect 2); and in front of the Gurupi River mouth (Transect 3).

\section{MATERIAL AND METHODS}

\section{Field dataset}

We have available one of the most complete CTD (Conductivity, Temperature, Depth) data sets obtained along the North Brazil zone, delimited by the $2.5^{\circ} \mathrm{S}$ and $7{ }^{\circ} \mathrm{N}$ latitudes and the longitudes $40^{\circ} \mathrm{W}$ and $51^{\circ} \mathrm{W}$. These measurements have been carried out in recent years during the Assessment of the Sustainable Potential of the Living Resources of the Exclusive Economic Zone (REVIZEE/ SCORE-NO, 1995-2001) cruise. The Conductivity (resolution $=0.00004$ S.m-1), Temperature (resolution $=0.0003^{\circ} \mathrm{C}$ ) and Pressure (resolution $=0.068$ ) data were measured with a Seabird SBE-19 during the 4 cruises. Each survey consisted of 24 Transects perpendicular to the coast spaced, field observations included 724 CTD continuous profiles with distance between the CTD profiles about $13 \mathrm{~km}$ near Amazon mouth and $55 \mathrm{~km}$ offshore (Fig. 1). Observations in section 3.2 include three Transects: about $500 \mathrm{~km}$ north of the Amazon river, in front of the Amazon river mouth and in front of the Gurupi river mouth (Fig. 1). In situ wind observations were available during REVIZEE cruises.

\section{Model description}

The CLIPPER Modelling Project is a French contribution to the World Ocean Circulation Experiment - WOCE (http://www.ifremer.fr/lpo/clipper/index.html). CLIPPER is a project of high resolution modeling of the Atlantic Ocean Circulation, either forced by air-sea fluxes or coupled with an atmospheric model. The model is a suite of Atlantic experiments carried out a $1 / 6^{\circ}$ Atlantic model simulation is forced with daily fluxes and has store 5 -day mean output every 5 days. A detailed description (algorithm and behaviour) of the open boundaries in the South Atlantic is found in TRÉGUIER et al. (2001). 
The atmospheric forcing in CLIPPER was derived from the ECMWF reanalysis monthly climatology, then integrated for the 15 years of the reanalysis (1979 to 1993), and then with the ECMWF analysis (1994-2000). The configurations are based on the OPA code (MADEC et al., 1998). The horizontal grid is defined on a Mercator projection with a spatial resolution (grid) of $1 / 6^{\circ}$ at the equator. Details of the model are documented in the article (report by the CLIPPER project team (2000)). The model is initialised using the seasonal climatology (temperature and salinity) of Reynaud et al. (1998). A new monthly climatology of the river contributions in fresh water forcing was especially elaborate from data provided by the publications of UNESCO (1996).

The vertical model grid has 42 geopotential levels with a grid spacing of $12 \mathrm{~m}$ close the sea surface increasing from $200 \mathrm{~m}$ below $1500 \mathrm{~m}$. In this work the layer 1 is calculated corresponding to the depth of $5 \mathrm{~m}$ during April 1995, May 1999 August 2001 and November 1997, which are directly comparable to the cruises observations. The major interest thought of the computation domain is analysed in a region of the North Brazil Zone characterized by the presence of the freshwater, proceeding from the Amazon River.

\section{RESULTS AND DISCUSSION}

\section{Sea Surface Salinity Seasonal variations}

Near-surface salinity contours were obtained as expected for four different stages in the annual hydrological cycle (Fig. 2). Surface salinity observations showed that the Amazon River forms a brackish Amazonian Water Lenses (AWL) that extends offshore and northwestward along the continental shelf during all periods of the REVIZEE cruises. This seasonal description has to be related to the seasonal variability of the Amazon River discharge, which is maximum in Spring (May/June), decreases in Summer (August/September) and minimum around November (OLTMAN, 1968; LENTZ and LIMEBURNER, 1995, SILVA et al., 2009). Next to the Amazon River mouth, near-surface contours show low-salinity $(<35.0)$ water, increasing with distance from the coast for both periods according to the scenario of each period. In front of the Amazon River mouth, the AWL extends for a further $300 \mathrm{~km}$ offshore during boreal Spring and $50 \mathrm{~km}$ during boreal Fall, always northeastward (Fig. $2 \mathrm{~b}$ and $2 \mathrm{~d}$ ). They have shown that Amazon water plumes may accumulate in the vicinity of the Amazon mouth in late Winter and Spring (Fig. 2a and 2b), due to wind events with a northeastward component, when the ITCZ shifts equatorward, which is consistent with the period of maximum precipitation in the region (Fig. 3a). These winds consequently impede or block the normally northwestward Amazon water flow (observed also by GEYER et al., 1996). The freshwater lens thus concentrates in a pool of increasing width and is only released northwestward when the wind reverses, blowing from the southeast during November (Fig. 3b). Map have shown a bigger concentration of the AWL in front Amazon mouth in Spring 1999 (Fig. 2b). This AWL tends to bend northwestward due to the NBC, but spreads all over the inner Amazon shelf during decreases and minimum discharge and over the entire shelf during maximum discharge. It was also noticed that during boreal late Winter and Spring the AWL moved southwestward along the coast north of the Brazil, decreasing during boreal Summer (Fig. 2a, b and c) and during boreal Fall this was not observed (observed also by LENTZ and LIMEBURNER, 1995). During boreal Summer and Fall a net reduction of AWL is observed, and only a small transfer is verified in the NW direction only, associated with NBC rings as discussed by Hu et al., 2004 and near $6^{\circ} \mathrm{N}$ retroflect for eastward via the NBC/NECC system (Fig. 2c and Fig. 5c). This scheme is associated to freshwaters dispersion around the eddies (as previously discussed by FRATANTONI and GLICKSON, 2002 and GARRAFO et al., 2003). 
SILVA, A. C. da; ARAUJO, M.; BOURLÈS, B. Seasonal variability of the Amazon river plume during Revizee program.
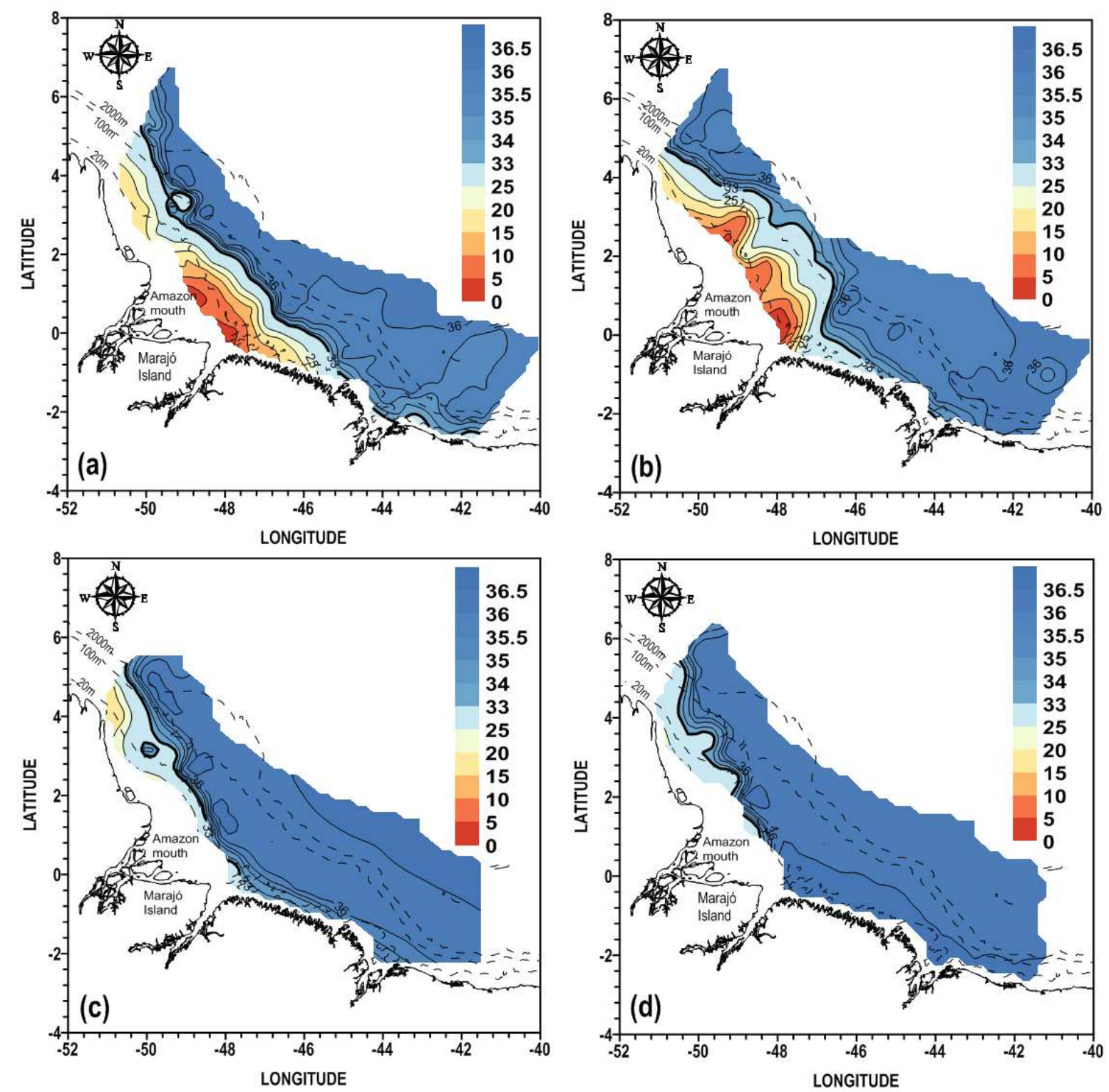

Figure 2 - Sea surface salinity distributions observed during 4 oceanographic cruise periods: (a) boreal late Winter/Spring (March-May 1995); (b) boreal Spring (May-June 1999); (c) boreal Summer (July-September 2001); (d) boreal Fall (October-December 1997). 


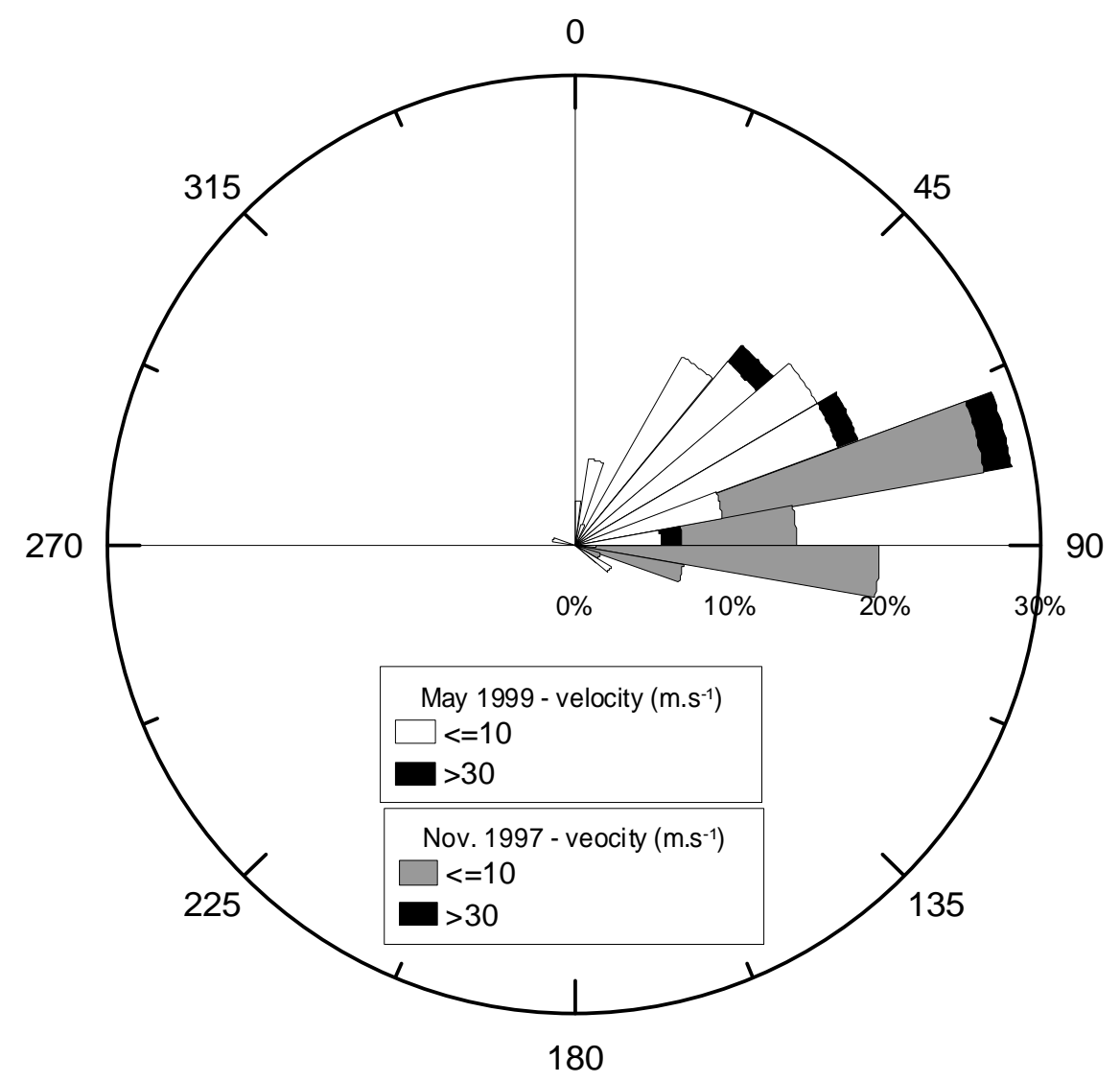

Figure 3 - Wind direction and intensity ( $m$ s-1) observations during REVIZEE cruises. Northeastward winds during May 1999 (a) and southeastward winds during November 1997 (b).

\section{Vertical distribution. Transect analysis.}

For a better understanding of the domain and variability of AWL found at the Amazon shelf and in the adjacent oceanic area during boreal Spring 1999 and boreal Fall 1997 correspondent to maximum and minimum Amazon river discharge periods, three Transects perpendicular to the coast are studied: about $500 \mathrm{~km}$ north of the Amazon River (Transect 01), in front of the Amazon River mouth (Transect 02) and Transect 03 in front of the Gurupi River mouth near $44^{\circ} \mathrm{W}$ (Fig. 1). In Transect 01, shown in Fig. $4 a$ and b, during October 1997 and May 1999, the AWL was identified by high temperature and low salinity, influenced by Amazon River's high discharge rates. This AWL occupied the entire water column at coastal stations until 20 - $30 \mathrm{~m}$ depth and its displacement was northwestward, parallel to the coast (Fig. 4a, b and Fig. 2). The same Transect shows the presence of a low salinity (33.0) extending to about $110 \mathrm{~km}$ offshore in May 1999 (estimates are based on Transect data), having the formation of the halocline around $20 \mathrm{~m}$ (observed also by LENTZ and LIMEBURNER, 1995). Below these surface waters, a high salinity core (36.6) may be observed over the Amazon shelf break. For comparative purposes, a salinity of hydrographic data measured for October 1997 shown the presence of a low salinity surface (33.0) reaching around $160 \mathrm{~km}$ and a high salinity core over the Amazon Shelf in Transect 01 (Fig. 4a).

During May 1999 (Fig. 4d) in Transect 02, AWL reached $300 \mathrm{~km}$ offshore from the coast, associated with southeastward winds may block the northwestward freshwater advection. During this period the water column is strongly stratified, resembling an estuarine salt wedge; the AWL over the Amazon shelf is about 10-20 m thick (in front of the Amazon River mouth) and during October 1997 not observed influences of the AWL, associated with minimum Amazon river discharge, shown in Fig. 4c.

Data measured at Transect 03 in June 1999 shows a maximum salinity core, with salinity ranging up to 36.4 , centered at $65 \mathrm{~m}$ deep, at a distance of about 170 and $230 \mathrm{~km}$ from the coast (Fig. 4f). The comparison of the vertical structure observed in November 1997 and in May 1999 shows that a high salinity core centered at 100m deep about $250 \mathrm{~km}$ 
SILVA, A. C. da; ARAUJO, M.; BOURLÈS, B. Seasonal variability of the Amazon river plume during Revizee program.

offshore is always present, this also does not demonstrate low salinity water in the surface (Fig. 4e).

The salinity cores observed in the transects may only be due to the signature of the NBC/NBUC system, penetrating into the region from the south and transporting northward SAW formed in the South Atlantic subtropical gyre (BOURLÈS et al., 1999; SILVA et al., 2009).
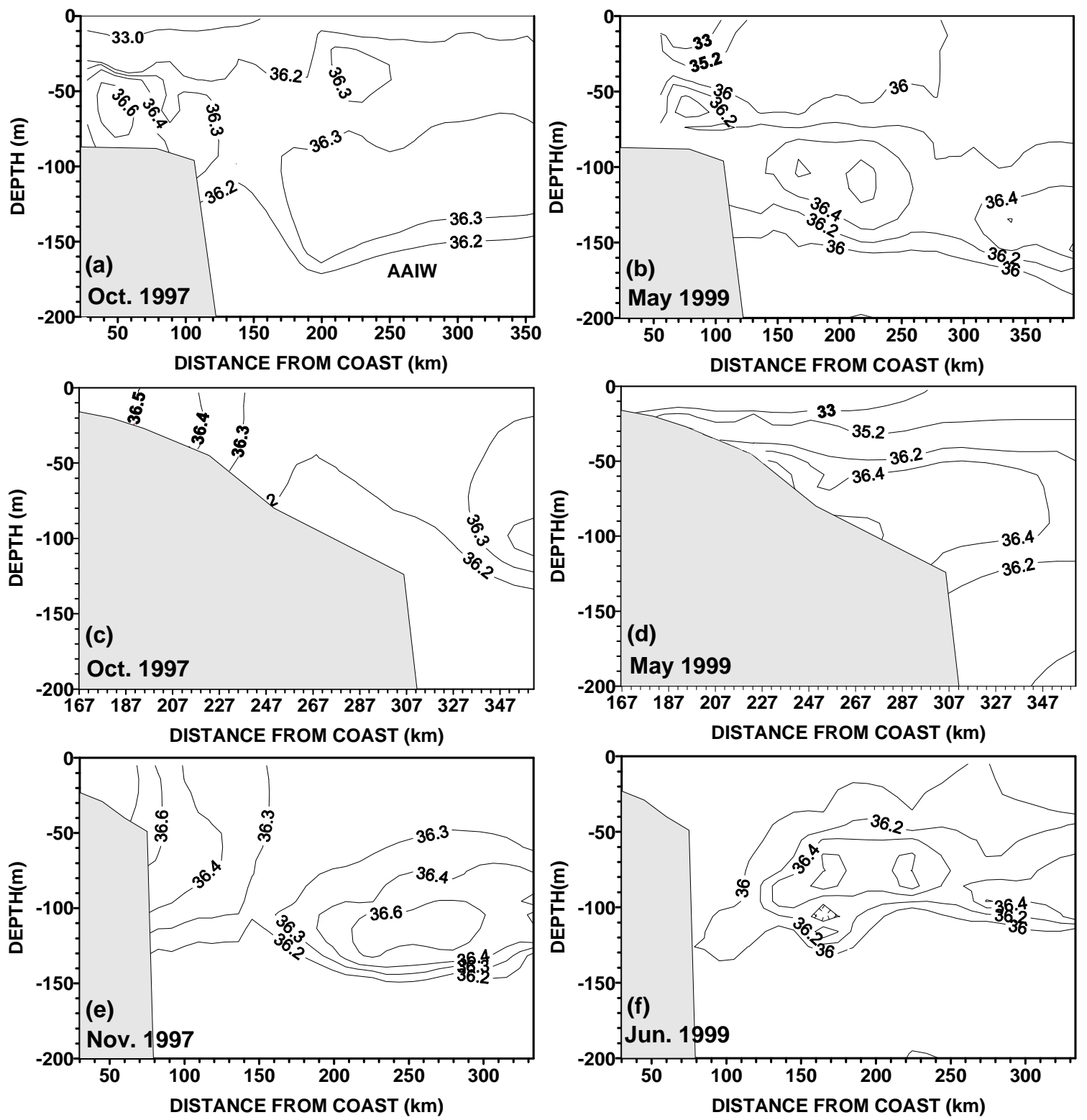

Figure 4 - Salinity sections along the Transect 01, obtained during 2 periods: (a) Oct. 1997, (b) May 1999; Transect 02 obtained during: (c) Oct.1997, (d) May 199 and Transect 03 obtained during: (e) Nov. 1997, (f) June 1999.

\section{Comparison with model results}

This seasonal description has to be related to the seasonal variability of the Amazon River discharge, which is maximum in Spring (May/June), decreases in Summer (August/September) and is low in Fall and Winter with a minimum around November (OLTMAN, 1968; LENTZ and LIMEBURNER, 1995). Our results show that AWL are encountered on large stretches and over the whole western tropical North Atlantic from early Summer to early Winter, i.e. a few months after the maximum Amazon discharge (the necessary period of time for the currents to carry the fresh waters in the region), and are present only as AWL remnants or isolated AWL in Winter and Spring, after the discharge is minimum but when it is rising. These patterns clearly indicate the correlation, with a time delay, between the seasonal variations of the Amazon discharge and the AWL presence. 
However, as the Amazon flow is never interrupted, the absence of AWL in Winter and Spring may appear surprising. Gibbs (1970) has already discussed the absence of large AWL offshore during the high river discharge season, in late Winter-Spring. He early suggested that fresh water could accumulate along the shelf of Brazil until it suddenly forms a very large lobe which may then be released seaward due to changes in the wind patterns. Clipper Model results registered in detail this phenomenon and explained the reasons for this apparent paradox (Fig. 5). They have shown that Amazon water plumes may accumulate in the vicinity of the Amazon mouth in Spring, due to wind events blowing from the northeast component, when the ITCZ shifts equatorward. These winds consequently hinder or block the normally northwestward Amazon water flow (Fig. 3). The fresh water lens thus concentrates in a pool of increasing width and is only released northwestward when the wind reverses to its usual southwestward direction (GEYER et al., 1996). This pattern explains the concentration in front of the Amazon mouth in May 1999 and April 1995 (Fig. $5 \mathrm{a}$ and 5b). During AMASSEDS in March 1990 this AWL corresponds to the very fresh water tongue observed (LENTZ, 1995b; LENTZ and LIMEBURNER, 1995; LIMEBURNER et al., 1995), following a period of southeastward winds and preceding a period of increasing salinity north of the Amazon mouth, once the AWL is left, until the maximum Amazon discharge in May. This feature of the AWL distribution registered in model results is in good agreement with many earlier synoptic observations.
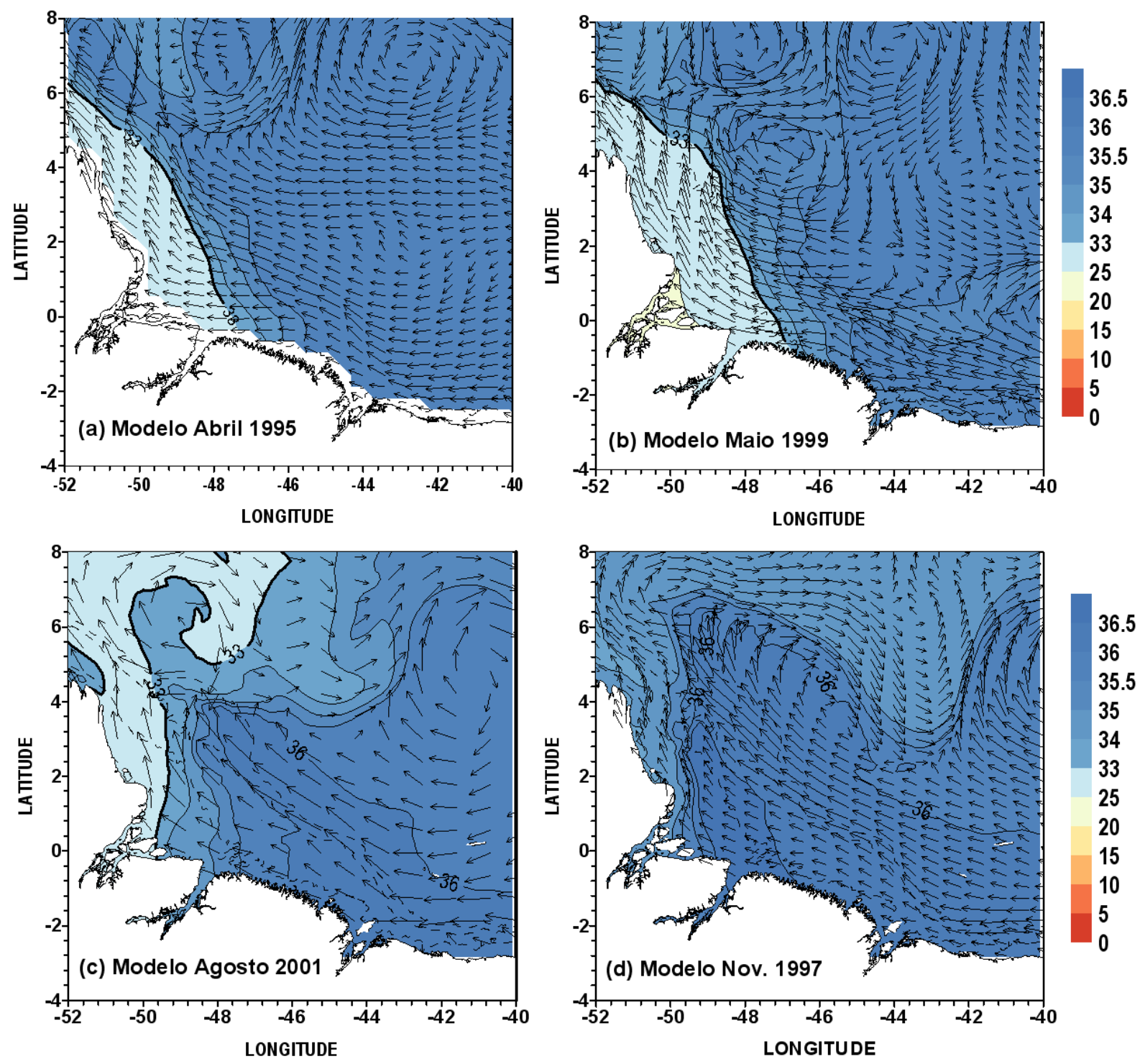

Figure 5 - Snapshot of the sea surface salinity obtained from CLIPPER model results in boreal Spring ((a) Apr. 95 (b) May 99), boreal Summer ((c) Aug. 2001), and boreal Fall ((d) Nov. 1997). 
SILVA, A. C. da; ARAUJO, M.; BOURLÈS, B. Seasonal variability of the Amazon river plume during Revizee program.

Dessier and Donguy (1994) have shown from objective analysis of sea surface salinity data collected by merchant ships and research vessels (1977 to 1989), as well as Lentz (1995a), from historical hydrographic data spanning from 1911 to 1987 , that the AWL was extends toward the north and northwest from January to June, but that theses lenses were partly deflected eastward in the NECC within the NBC retroflection from July to December. Lentz (1995a) also estimates that almost $70 \%$ of the Amazon plume waters are carried eastward while the remaining $30 \%$ flows toward the Caribbean in Summer-Fall. Model results registered above are in rather good agreement with these mean patterns in Summer and during the NBC retroflection (Fig. 5c). In Summer, the observed patterns are closer to the climatology: as explained by our surface currents results, a large portion of the fresh water plume is advected eastward within the NECC. This scheme, associated to fresh waters dispersion around the eddies (as discussed by FRANTANTONI, 2002), is also in agreement with Lentz analysis (1995a). The apparently continuous fresh waters flow along the coast suggested either by climatology (DESSIER and DONGUY, 1994; LENTZ, 1995a) or CZCS imagery (MÜLLER-KARGER et al., 1988) can be explained by the use of historical data and smoothing analysis or composites of images respectively. In the same way, Lentz (1995a) observes from historical data a large area of low-salinity waters far away from the coasts, from January through June. He suggests that the Amazon waters are carried northwestward in the NBC, defined as a permanent and continuous northwestward boundary current throughout the year (RICHARDSON et al., 1994). The northwestward flow of the Amazon fresh waters, if it exists at this period of the year, could consequently only be due to a coastal flow trapped on the continental shelf. In Apr-June, following the Brazil rainy season and maximum Amazon discharge, a very large amount of fresh waters pour out through the whole region, along the coast and within the NBC current.

An interesting question that remains open concerns the fact that the "isolated" AWL evidenced during Spring does not propagate eastward. Molinari et al. (1983) observed a drifter moving eastward through the region until March, suggesting that the retroflection may be present still in later Winter. From historical temperature data, Molinari and Johns (1994) show that the retroflection, at the level of the $20^{\circ} \mathrm{C}$ isotherm, is a quasi-permanent feature of the circulation, diminishing in March and only remnant in June. Model results indicate that the retroflection is also present in April 1995 around $8^{\circ} \mathrm{N}$, not registered in May 1999 (Fig. 5a and 5b). However, the minimum Amazonian discharge, the wind regime with southeast component events off the Amazon mouth (LENTZ, 1995b) and the vanishing of the retroflection are certainly the main contributions leading to the absence of eastward propagating AWL in Winter-Spring. Further studies have to be carried out to confirm this hypothesis and to quantify the relative importance of each of these phenomena.

\section{AKNOWLEDGEMENTS}

We thank Dr. Anne Marie Tréguier for providing the model results (Laboratoire de Physique des Océans/Brest-France). Special thanks to Dr. Maâmar El-Robrini (UFPA), as well as the scientific and crew members of the R/V Antares (DHN/Brazilian Navy), for their efforts and dedication during REVIZEE oceanographic cruises. This work was supported by CAPES/BRAZIL (Coordination for the Improvement of Higher Education Personnel, Brasília, Brazil) and LEGOS/FRANCE (Centre IRD de Brest, Plouzané, France).

\section{REFERENCES}

BAUMGARTNER, A.; REICHEL, E. The world water balance. New-York: Elsevier, 1975. 179 p.

Cadee, G.C. Primary production off the Guyana coast. Neth. J. Sea Res., v. 9, p. 126-143, 1975.

BOURLÈS, B.; GOURIOU, Y.; CHUCHLA, R. On the circulation in the upper layer of the western equatorial Atlantic. J. Geophys. Res., v. 104, p. 21151-21170, 1999.

CALEF, G.W.; GRICE, G.D. Influence of the Amazon river outflow on the ecology of the western Tropical Atlantic; II. Zooplankton abundance, copepod distribution, with remarks on the fauna of low salinity areas. J. Mar. Res., v. 25, p. 84-94, 1967.

CARTON, J.A. Effect of seasonal surface freshwater flux on sea surface temperature in the Tropical Atlantic Ocean. J. Geophys. Res., v. 96, p. 12593-12598, 1991. 
CLIPPER PROJECT TEAM, 2000: $1 / 6^{\circ}$ Atlantic Circulation model forced by the ECMWF climatology: preliminary results. LEGI report number CLIPPER-R2-2000, also available at www.ifremer.fr/lpo/clipper.

DESSIER, A.; DONGUY, J.R. The sea-surface salinity in the Tropical Atlantic between $10^{\circ} \mathrm{S}$ and $30^{\circ} \mathrm{N}$-seasonal and interannual variations (1977-1989). Deep-Sea Res., v. 41(1), p. 81-100, 1994.

FFIELD, A. North Brazil Current rings viewed by TRMM Microwave Imager SST and the influence of the Amazon plume. Deep-Sea Res. I, v. 52, p. 137-160, 2005.

FRATANTONI, D.M.; GLICKSON, D.A. North Brazil Current ring generation and evolution observed with SeaWiFS. J. Phys. Oceanogr., v. 32, p. 1058-1074, 2002.

FROELICH, P.N.; ATWOOD, D.K.; GIESE, G.S. Influence of Amazon River discharge on surface salinity and dissolved silicate concentration in the Caribbean Sea. Deep-Sea Res., v. 25, p. 735-744, 1978.

GARRAFO, Z.D.; JOHNS, W.E.; CHASSIGNET, E.P.; GONI, G.J. North Brazil Current rings and transport of southern water in a high resolution numerical simulation of the North Atlantic, in Interhemispheric Water Exchanger in the Atlantic Ocean. Elsevier Oceanographic Series, v. 68, p. $375-409,2003$.

GARZOLI, S.L.; FFIELD, A.; JOHNS, W.E.; YAO, Q. North Brazil Current retroflection and transports. J. Geophys. Res., v. 109, CO1013, doi:10.1029/2003JC001775, 2004.

GEYER, W.R.; BEARDSLEY, R.C.; LENTZ, S.J.; CANDELA, J.; LIMEBURNER, R.; JOHNS, W.E.; CASTRO, B.M.; SOARES, I.D. Physical oceanography of the Amazon shelf. Cont. Shelf Res., v. 16, p. 575-616, 1996.

GIBBS, R.J. Circulation on the Amazon River estuary and adjacent Atlantic ocean. J. Mar. Res., v. 28(2), p. 113-123, 1970.

HU, C.; MONTGOMERY, E.T.; SCHMITT, R.W.; MÜLLER-KARGER, F.E. The Amazon and Orinoco River plumes in the tropical Atlantic and Caribbean Sea: Observation from space and S-PALACE floats. Deep-Sea Res., II, p. 1152-1171, 2004.

JOHNS, W.E.; BEARDSLEY, R.C.; CANDELA, J.; LIMEBURNER, R.; CASTRO, B. Annual cycle and variability of the North Brazil Current. J. Phys. Oceanogr., v. 28, p. 103-128, 1998.

KIDD, R.; SANDER, F. Influence of Amazon River discharge on the marine production system off Barbados, West Indies. J. Mar. Res., v. 37(4), p. 669-681, 1979.

LENTZ, S. Seasonal variations in the horizontal structure of the Amazon plume inferred from historical hydrographic data. J. Geophys. Res., v. 100(2), p. 2391-2400, 1995a.

LENTZ, S. The Amazon river plume during AMASSEDS: Subtidal current variability and the importance of wind forcing. J. Geophys. Res., v. 100(2), p. 2377-2390, 1995b.

LENTZ, S.; LIMEBURNER, R. The Amazon river plume during AMASSEDS: Spatial characteristics and salinity variability. J. Geophys. Res., v. 100(2), p. 2355-2375, 1995.

LIMEBURNER, R.; BEADSLEY, R.C.; SOARES, I.D.; LENTZ, S.J.; CANDELA, J. Lagrangian flow observations of the Amazon River discharge into the North Atlantic. J. Geophys. Res., v. 100(2), p. 2401-2415, 1995.

MADEC, G.; DELECLUSE, P.; IMBARD, M.; LEVY, C. OPA 8.1 general circulation model reference manual. Notes de I'IPSL, Université $P$. et M. Curie, B102 T15-E5, 4 place Jussieu, Paris cedex 5, N 11, 1998. 91 p.

MOLINARI, R.L.; FIEUX, M.; KLAUS, Z. Drifting buoy trajectories in the North Brazilian Coastal Current and North Equatorial Countercurrent. Tropical Ocean-Atm. Newsletter, 1983. 15 p.

Molinari, R.L.; Johns, E. Upper layer temperature structure of the Western Tropical Atlantic. J. Geophys. Res., v. 99(18), p. 225-18233, 1994.

MÜLLER-KARGER, F.E.; MCCLAIN, C.R.; RICHARDSON, P. The dispersal of Amazon's water.

Nature, v. 333, p. 56-59, 1988. 
SILVA, A. C. da; ARAUJO, M.; BOURLÈS, B. Seasonal variability of the Amazon river plume during Revizee program.

OLTMAN, R.E. Reconnaissance investigations of the discharge and water quality of the Amazon river. U S Geol Surv, Circ. 552, 1968. 16 p.

PAILLER, K.; BOURLÈS, B.; GOURIOU, Y. The barrier layer in the western Atlantic Ocean. Geophys. Res. Let., v. 26, p. 2069-2072, 1999.

PROST, M.T. Coastal dynamics and chenier sands in French Guiana. in Cheniers and Chenier Plains, P.G.E.F. Augustinus. Mar. Geol., v. 90, p. 259-267, 1989.

REYNAUD, T.; LEGRAND, P.; MERCIER, H.; BARNIER, B. A new analysis of hydrographic data in the Atlantic and its application to an inverse modelling study. International WOCE Newsletter, v. 32, p. 29-31, 1998.

RICHARDSON, P.L.; HUFFORD, G.; LIMEBURNER, R.; BROWN, W. North Brazil Current retroflection eddies. J. Geophys. Res., v. 99(3), p. 5081-5093, 1994.

RICHEY, J.E.; NOBRE, C.; DESSER, C. Amazon River discharge and climate variability: 19031985. Science, v. 246, p. 101-103, 1989.

RYTHER, J.H.; MENZEL, D.W.; CORWIN, N. Influence of the Amazon River outflow on the ecology of the Western Tropical Atlantic, I Hydrography and nutrient chemistry. J. Mar. Res., v. 25(1), p. 69-83, 1967.

SANTOS, M. L. S.; MEDEIROS, C. ; MUNIZ, K.; FEITOSA, F. A. N; SCHWAMBORN, R.;MACEDO, S. J. Influence of the Amazon and Pará Rivers on Water Composition and Phytoplankton Biomass on the Adjacent Shelf. J. of Coastal Res., v. 24, p. 585-593, 2008.

SILVA, A. C.; BOURLÈS, B.; ARAUJO, M. Circulation of the thermocline salinity maximum waters off the northern Brazil as inferred from in situ measurements and numerical results.

Ann. Geophys., v. 27, p. 1861-1873, 2009.

SILVA, A. C.; SANTOS, M. L. S.; ARAUJO, M.; BOURLÈS, B. Observações hidrológicas e resultados de modelagem no espalhamento sazonal e espacial da pluma de água Amazônica.

Acta Amazon., v. 39, p. 361-370, 2009.

TREGUIER, A. M.; BARNIER, B.; DE MIRANDA, A. P.; MOLINES, J. M.; GRIMA, N.; IMBARD, M.; MADEC, G.; MESSAGER, C.; REYNAUD T.; MICHEL. S. An eddy permitting model of the Atlantic Circulation: evaluating open boundary conditions. J. Geophys. Res., v. 106, p. 22115-22129, 2001.

UNESCO, 1996. Global River Discharge Data Base. Vol. I: Africa, Vol. II: Asia, and Vol. III: Europe.

YOO, J.M.; CARTON, J.A. Annual and interannual variations of the freshwater budget in the Tropical Atlantic Ocean and the Caribbean Sea. J. Phys. Oceanogr., v. 20(6), p. 831-845, 1990. 